\title{
Comparison of different surface disinfection treatments of drinking water facilities from a corrosion and environmental perspective
}

\author{
Valentin Romanovski $^{1,2,3} \cdot$ Per Martin Claesson ${ }^{1,4} \cdot$ Yolanda Susanne Hedberg $^{1}$ (D)
}

Received: 30 October 2019 / Accepted: 21 January 2020 / Published online: 1 February 2020

(C) The Author(s) 2020

\begin{abstract}
Surface disinfection of water facilities such as water wells requires measures that can remove pathogens from the walls to ensure a high drinking water quality, but many of these measures might increase corrosion of the contact surfaces (often highly pure steel) and affect the environment negatively due to disinfectant-contaminated waste sludge and wastewater. Today, most treatments worldwide are based on hypochlorites. We investigated the extent of corrosion during treatments of steel at relevant conditions of ozone, sodium, and calcium hypochlorite for drinking water preparation, utilizing weight loss, electrochemical, solution analytical, and surface analytical methods. The ozone treatment caused significantly less corrosion as compared with sodium or calcium hypochlorite with 150-250 mg/L active chlorine. Hypochlorite or other chlorine-containing compounds were trapped in corrosion products after the surface disinfection treatment with hypochlorite, and this risked influencing subsequent corrosion after the surface disinfection treatment. A life cycle impact assessment suggested ozone treatment to have the lowest negative effects on human health, ecosystems, and resources. Calcium hypochlorite showed the highest negative environmental impact due to its production phase. Our study suggests that ozone surface disinfection treatments are preferable as compared with hypochlorite treatments from corrosion, economic, and environmental perspectives.
\end{abstract}

Keywords Surface disinfection · Water facility $\cdot$ Groundwater $\cdot$ Corrosion $\cdot$ Life cycle assessment $\cdot$ Environmental impact

Responsible Editor: Bingcai Pan

Electronic supplementary material The online version of this article (https://doi.org/10.1007/s11356-020-07801-9) contains supplementary material, which is available to authorized users.

Valentin Romanovski

vramano@kth.se

$\triangle$ Yolanda Susanne Hedberg

yolanda@kth.se

1 Department of Chemistry, School of Engineering Sciences in Chemistry, Biotechnology and Health, Division of Surface and Corrosion Science, KTH Royal Institute of Technology, SE-100 44 Stockholm, Sweden

2 Center of Functional Nano-Ceramics, National University of Science and Technology "MISIS", Moscow, Russia 119049

3 Institute of General and Inorganic Chemistry, National Academy of Sciences of Belarus, 220072 Minsk, Belarus

4 RISE Research Institutes of Sweden, Bioscience and Materials Surface, Process and Formulation, SE-114 86 Stockholm, Sweden

\section{Introduction}

Drinking water facilities are regularly decontaminated by surface disinfection treatments to inactivate pathogens and microorganisms. This disinfection of internal surface of water supply facilities should be carried out at least once a year, and additionally in the case of viruses and microorganisms in the water. This is for example accomplished by chlorinecontaining reagents, such as sodium and calcium hypochlorite (American Water Works Association 2013, Jackson et al. 2001, Salvato 1992). The treatment with chlorine-containing substances is used worldwide. As an alternative, ozone was suggested for surface disinfection of water facilities (Schulz \& Lohman 2005), where the surfaces to be decontaminated are often made of low-alloyed steel. This treatment has been used and studied for stainless steels and in the food industry before (Greene et al. 1993, Guzel-Seydim et al. 2004), and was found to be beneficial as compared with chlorine-based disinfectants from an environmental perspective (Pascual et al. 2007). It has also been used for the drinking water preparation in some countries (Geering 1999, Rakness 2011), while others totally rely on chlorine-based disinfection. One important aspect 
when choosing surface disinfection treatment is the short- and long-term corrosion expected by the different surface disinfection treatments. Studies comparing different surface disinfection treatments for low-alloyed steel used in the preparation of drinking water in water wells are rare.

Regular surface disinfection treatments are a necessity, but some of these, or their by-products, may be hazardous for the environment and health (Bull 1982, Jeong et al. 2012, Villanueva et al. 2003). One example is disposal of chlorinecontaining sewage that is collected after treatment, which can be hazardous to the environment (Bayo et al. 2009). The disinfection also results in accelerated material degradation. This may lead to increased corrosion even after the treatment period, if disinfectants would be trapped in pores or cracks. Treatment times are usually 6-24 h for chlorine-based treatments, but only $0.5 \mathrm{~h}$ for ozone treatment (Романовский et al. 2016).

The current amount of sodium hypochlorite used in the European Union is in the range of 1,000,000-10,000,000 tons per annum (ECHA 2019b), while the registered amount of calcium hypochlorite is $0-10$ tons per annum (ECHA 2019c). Sodium hypochlorite is currently classified as "H400 Very toxic to aquatic life" and "H410 Very toxic to aquatic life with long-lasting effects" by the European Chemical Agency (ECHA 2016). Calcium hypochlorite is also classified as "H400 Very toxic to aquatic life" (ECHA 2016). On a consumption basis, sodium hypochlorite accounted for $91 \%$ of the total global hypochlorite use, with calcium hypochlorite making up the rest (IHS Markit 2015). Consumption of sodium hypochlorite in laundry bleach applications currently accounts for $67 \%$ of its use, with disinfectant use accounting for the remaining 33\% (IHS Markit 2015). Thus, the use of hypochlorite is significant, and a change to less harmful chemicals, such as ozone (Bhuvaneshwari et al. 2019, Dong et al. 2018, Sun et al. 2018), could result in environmental and health benefits. Comparative quantitative and qualitative data on corrosion induced by hypochlorite and ozone surface disinfection treatments would in addition provide knowledge on technological, economic, and societal consequences of different surface disinfectant treatments for lowalloyed steel in water well facilities for the preparation of municipal drinking water.

The objectives of this study were (i) to compare lowalloyed steel corrosion for relevant surface disinfection treatments using hypochlorite-based and ozone-based methods, (ii) to estimate any increased subsequent corrosion after surface disinfection treatment, and (iii) to provide a life cycle impact assessment of the different surface disinfection treatments. Note that this study is devoted to the disinfection of the internal surface of water supply facilities (water boreholes, filters, pipes, reservoirs) and not to disinfection of water volume on the way to households, which would require much lower concentrations of disinfectants.

\section{Materials and methods}

\section{Materials and sample preparation}

The material used in the present work was steel for water well pipes (standard: EN 10130/91; quality: Fe P01 A). Its nominal composition (wt $\%$ ), iron (balance), $0.06 \mathrm{wt} \% \mathrm{C}, 0.22 \mathrm{wt} \%$ Mn, 0.01 wt $\%$ Si, 0.014 wt\% P, 0.014 wt $\%$ S, 0.047 wt $\%$ $\mathrm{Al}$, and $0.006 \mathrm{wt} \% \mathrm{~N}$, is similar to that analyzed in steel samples from different water facilities (Table S1, supplementary information).

Steel samples with a thickness of $1.5 \mathrm{~mm}$ and dimensions of $15 \times 15 \mathrm{~mm}$ were abraded with emery papers down to FEPA P 1200\# SiC grit and then polished using short synthetic DP-Nap and diamond pastes (down to $1 \mu \mathrm{m}$ ) DP-Stick P Struers. The samples were thereafter washed with ultrapure water (18.2 M $\Omega$ cm, Milli-Q system, Millipore, Sweden), degreased ultrasonically by acetone and ethanol (for $5 \mathrm{~min}$ each), and dried with nitrogen gas at room temperature $(\approx$ $21{ }^{\circ} \mathrm{C}$ ). All steel samples were then kept in a desiccator at room temperature for $24 \pm 2 \mathrm{~h}$ prior to testing.

\section{Solutions and disinfection agents}

Experiments were carried out in solutions based on artificial tap water (ISO 6341:2012 2012). The composition of the artificial tap water was as follows: $65.7 \mathrm{mg} / \mathrm{L} \mathrm{NaHCO}_{3}$, $5.75 \mathrm{mg} / \mathrm{L} \mathrm{KCl}, 123.0 \mathrm{mg} / \mathrm{L} \mathrm{MgSO}_{4} \cdot 7 \mathrm{H}_{2} \mathrm{O}, 294.0 \mathrm{mg} / \mathrm{L}$ $\mathrm{CaCl}_{2} \cdot 2 \mathrm{H}_{2} \mathrm{O}$, pH 7.5 (adjusted by $1 \% \mathrm{HNO}_{3}$ ). The disinfectants used were $\mathrm{NaClO}$ (initial concentration $3.5 \mathrm{~g} / \mathrm{L}$ of active chlorine, VWR chemicals, France) and $\mathrm{Ca}(\mathrm{ClO})_{2}(99.95 \%$, initial concentration $65 \%$ of active chlorine, Alfa Aesar, Germany). The corrosion experiments were performed in aqueous solutions of hypochlorite with 50, 150, and $250 \mathrm{mg} /$ $\mathrm{L}$ of active chlorine. The active chlorine or free chlorine is known as a hypochlorite ion $\mathrm{OCl}^{-}$concentration (Brandt et al. 2016). The concentrations used are relevant for disinfection of water treatment facilities (American Water Works Association 2013, Jackson et al. 2001, Salvato 1992).

Ozone was generated by utilizing an Internal ozone generator (Model O341M Environment S.A). The ozone concentration in the outlet was $0.75 \mathrm{mg} / \mathrm{m}^{3}$ and the flow rate was $4 \mathrm{~L} /$ min, resulting in an ozone concentration of $0.36 \mathrm{mg} / \mathrm{L}$ in a $250 \mathrm{~mL}$ cell after 30 min treatment, which is a relevant concentration for surface disinfection (World Health Organization 2011). All chemicals used in this study were of p.a. or puriss. p.a. grade (in the case of metal release investigations). The solvent for all solutions was ultrapure water.

\section{Surface morphology and composition}

The surface morphology and surface composition (with $\mu \mathrm{m}$ resolution) were determined prior to and after treatment using 
a tabletop scanning electron microscope (SEM) with backscattered electron analysis (Hitachi TM-1000) coupled to energy X-ray dispersive spectroscopy (EDS). The microstructure and chemical composition of the scratched-off corrosion products were studied by SEM using a JEOL F7600 equipped with backscattered electrons (BSE) and EDS. At least two samples were investigated for each condition. The surface analyses were conducted with magnifications up to $\times$ 20,000 for a minimum of 10 different locations.

\section{Raman spectroscopy}

A Horiba HR800 instrument was used for confocal Raman spectroscopy measurements, using a 514-nm laser (no filter), a $500-\mu \mathrm{m}$ pinhole, and an Olympus $\times 50(0.25 \mathrm{NA})$ objective. The sample was inspected before and after analysis to ensure no laser-induced oxidation.

\section{Corrosion estimations and electrochemical measurements}

Weight loss measurements were carried out for up to $24 \mathrm{~h}$ of treatment in closed glass flasks in artificial tap water, artificial tap water containing $\mathrm{NaClO}$ or $\mathrm{Ca}(\mathrm{ClO})_{2}$, or in artificial tap water treated with ozone during the first $30 \mathrm{~min}$. The exposed surface area of the samples was 3.9 or $4.7 \mathrm{~cm}^{2}$ in a $10-\mathrm{mL}$ solution. The samples were taken out from the solutions after $6,12,18$, and $24 \mathrm{~h}$, rinsed by $2 \mathrm{wt} \%$ citric acid solution (during about $10 \mathrm{~s}$ ) in order to remove the corrosion products formed (Varga et al. 2001), rinsed by deionized water, and dried by nitrogen gas. This procedure did visually remove corrosion products without attacking the metal. The samples were then weighed with $0.1 \mathrm{mg}$ accuracy using a balance (Mettler Toledo), and the weight was compared with their initial weight. All weight loss measurements were replicated on three parallel samples. Both the treatment solution and the citric acid solution used for removal of corrosion products were analyzed to determine their iron concentration, as described in the next section.

Electrochemical measurements consisted of open-circuit potential (OCP) and potentiodynamic polarization scans. The multichannel Princeton Applied Research AMETEK potentiostat was used with three-electrode cells $(250 \mathrm{~mL})$ using a $\mathrm{KCl}$ saturated $\mathrm{Ag} / \mathrm{AgCl}$ reference electrode, a Ptmesh counter electrode, and the steel sample as the working electrode. The exposed area of the sample was $0.785 \mathrm{~cm}^{2}$. All measurements were performed at room temperature $\left(\approx 21^{\circ} \mathrm{C}\right)$ and replicated at least three times. The OCP curves were measured each second during $24 \mathrm{~h}$. The potentiodynamic curves were obtained in the potential range $-0.25 \mathrm{~V}$ to $+1.0 \mathrm{~V}$ (vs. OCP, which was first determined during $5 \mathrm{~min}$ ) with a scan rate of $0.5 \mathrm{mV} / \mathrm{s}$. Electrochemical parameters were extracted from the polarization curves using the Levenburg-Marquardt method (Gavin 2019) in the VersaStudio software (2017).

\section{Iron determination in solutions}

Solution metal analysis was performed using atomic absorption spectroscopy (AAS, AAnalyst 800 instrument, Perkin Elmer) in the flame mode. Calibration curves were based on at least four calibration standards, which were covering the sample concentrations, and quality control samples of known concentration were analyzed regularly. The limits of detection, as determined by three times the highest standard deviation of the blank samples, were approximately $0.2-1 \mathrm{mg} / \mathrm{L}$, depending on the calibration standards used. All sample concentrations exceeded the limits of detection and were higher than in the corresponding blank (background solutions without any contact with steel). The reported concentration of iron in solution is based on the average concentration of three independent replicate samples with the corresponding blank concentration subtracted. The error bars in the figures show the standard deviation of three independent samples. For all samples, the aqueous iron concentration immediately after treatment and the iron concentrations resulting from dissolving the rust with citric acid and nitric acid were determined (Fig. S1 (supplementary information)). The rust that could not be dissolved by citric acid and nitric acid was examined by EDS.

\section{Chemical speciation modeling}

The Joint Expert Speciation System (JESS, (May 2015)) was used to model the chemical speciation of iron species in the different solutions. As input values, $1.8 \mathrm{mM} \mathrm{Fe}^{3+}$, a temperature of $25{ }^{\circ} \mathrm{C}$, atmospheric pressure, $0.782 \mathrm{mM} \mathrm{CO}_{3}{ }^{2-}$, $0.0771 \mathrm{mM} \mathrm{K}^{+}, 0.499 \mathrm{mM} \mathrm{SO}_{4}{ }^{2-}$, and $0.499 \mathrm{mM} \mathrm{Mg}^{2+}$ were used for all cases, while the concentrations of $\mathrm{Na}^{+}, \mathrm{Ca}^{2+}, \mathrm{Cl}^{-}$, the $\mathrm{pH}$, and the redox potential were varied as shown in Table 1 . The redox potential was increased for increasing hypochlorite concentration in order to simulate the increasing oxidizing potential. Precipitation of solid species was allowed (and investigated). Thirty-five different solids of different iron compounds were identified and included by the chemical speciation system.

\section{Life cycle analysis and life cycle cost analysis}

The software SimaPro 8.04.26 including the research method ReCiPe Endpoint (I) V1.11/Europe ReCiPe I/A was used to assess the impact of the surface disinfectants on the environment during their life cycle. The evaluation method ReCiPe Endpoint (I) has three endpoints: damage to human health, ecosystem quality, and damage to resource (Goedkoop et al. 2009, Sleeswijk et al. 2008). The basic unit of overall environmental impacts was $\mathrm{Pt}$ (point-standard eco-indicator 
Table 1 Varying input values in JESS modeling for the different solutions investigated. a.ch., active chlorine

\begin{tabular}{llllll}
\hline Solution & $\mathrm{Na}^{+}(\mathrm{mM})$ & $\mathrm{Ca}^{2+}(\mathrm{mM})$ & $\mathrm{Cl}^{-}(\mathrm{mM})$ & $\mathrm{pH}$ & Redox potential (pe) \\
\hline Artificial tap water $(\mathrm{ATW})$ & 0.782 & 2.00 & 4.08 & 7.5 & 5 \\
ATW + 50 mg/L a.ch. $\mathrm{NaClO}$ & 5.83 & 2.00 & 5.05 & $9 ; 8.3$ & 6 \\
ATW + $150 \mathrm{mg} / \mathrm{L}$ a.ch. $\mathrm{NaClO}$ & 7.77 & 2.00 & 6.99 & $9.7 ; 8.5$ & 8 \\
ATW + 250 mg/L a.ch. $\mathrm{NaClO}$ & 9.72 & 2.00 & 8.94 & $10 ; 8.6$ & 10 \\
ATW + 50 mg/L a.ch. $\mathrm{Ca}(\mathrm{ClO})_{2}$ & 0.782 & 4.52 & 5.05 & $8.5 ; 8.2$ & 6 \\
ATW + 150 mg/L a.ch. $\mathrm{Ca}(\mathrm{ClO})_{2}$ & 0.782 & 5.50 & 6.99 & $8.6 ; 8.2$ & 8 \\
ATW + 250 mg/L a.ch. $\mathrm{Ca}(\mathrm{ClO})_{2}$ & 0.782 & 6.47 & 8.94 & $8.7 ; 8.2$ & 10 \\
\hline
\end{tabular}

normalized unit). In LCA, for the method ReCiPe Endpoint (I), 17 different impact categories (midpoints) were analyzed in detail, as human toxicity was split up into "carcinogens" and "non-carcinogens." Baseline data for the calculation was taken from the preparation conditions of $1 \mathrm{~m}^{3}$ of disinfectant solution with concentration $150 \mathrm{mg}$ active chlorine/L (or $1 \mathrm{mg} / \mathrm{L}$ ozone). The efficiency of the use of raw materials in the preparation of reagents was assumed to be $90 \%$. Further details are given in the supplementary material (Figs. S2-S5, Tables S2-S4).

\section{Statistical significance}

Statistically significant differences between sample data sets were estimated by Student's $t$ test for unpaired data of unequal variance in the KaleidaGraph v.4.0 software.

\section{Results}

When evaluating the corrosion behavior, we considered relevant treatment times needed for surface disinfection by hypochlorites (typically 12-24 h) and by ozone (typically $30 \mathrm{~min}$ ) (Романовский et al. 2016).
Weight loss experiments revealed a decreasing corrosion rate with time for all conditions tested. The weight loss of the samples was similar in sodium and calcium hypochlorite, and increased with increasing hypochlorite concentration (Fig. 1). The weight loss in ozonated artificial tap water was comparable or slightly lower than the weight loss of the samples in sodium and calcium hypochlorite at their lowest concentration of $50 \mathrm{mg} / \mathrm{L}$ active chlorine. After $24 \mathrm{~h}$, the weight loss of steel in ozonated water was $2.1 \mathrm{~g} / \mathrm{m}^{2}$, which is a factor of 2-3 less than in $150 \mathrm{mg} / \mathrm{L}$ active chlorine of sodium and calcium hypochlorite, and 20-30\% less than in $50 \mathrm{mg} / \mathrm{L}$ active chlorine. The corrosion rate of steel in 30 min ozonated artificial tap water was 1.5 -fold higher than in non-ozonated water.

Next, we determined the effect of previous disinfection treatments on corrosion of the steel samples. After the initial disinfection treatment for $24 \mathrm{~h}\left(\mathrm{NaClO}, \mathrm{Ca}(\mathrm{ClO})_{2}\right.$, or ozone during the first $30 \mathrm{~min}$ followed by no additional ozone during $23.5 \mathrm{~h}$ ), all samples were taken out from the treatment solution, washed by ultrapure water, and immersed into fresh artificial tap water for $24 \mathrm{~h}$. The last time point of $48 \mathrm{~h}$ in Fig. 1 shows this subsequent artificial tap water exposure. The weight loss increased further in all cases, however at a significantly lower rate as compared with the initial $24 \mathrm{~h}$ (Fig. 1).
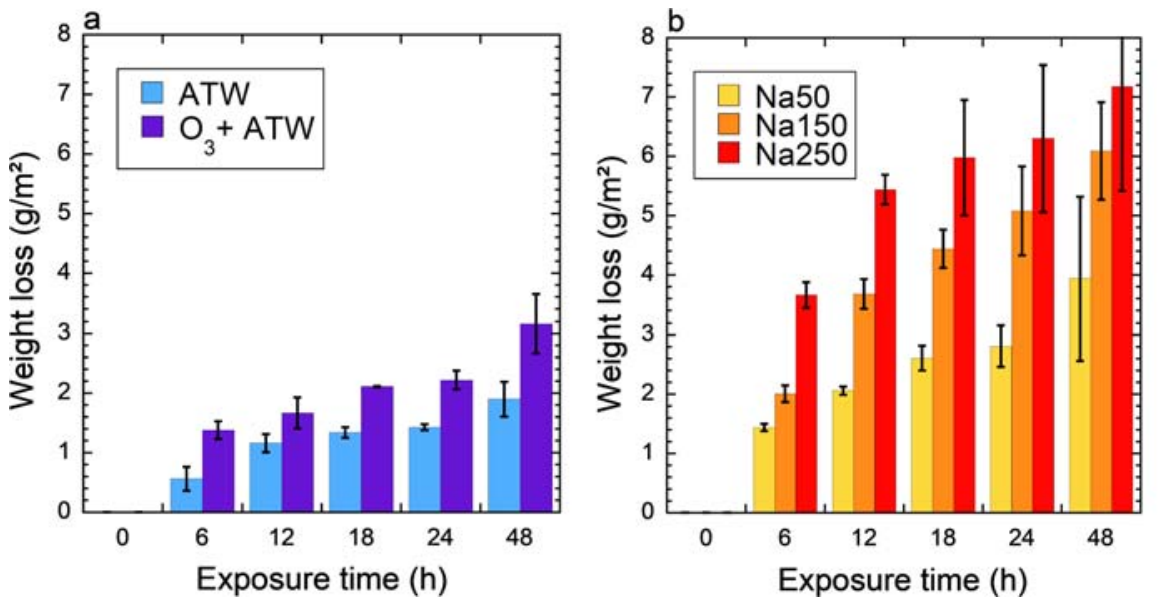

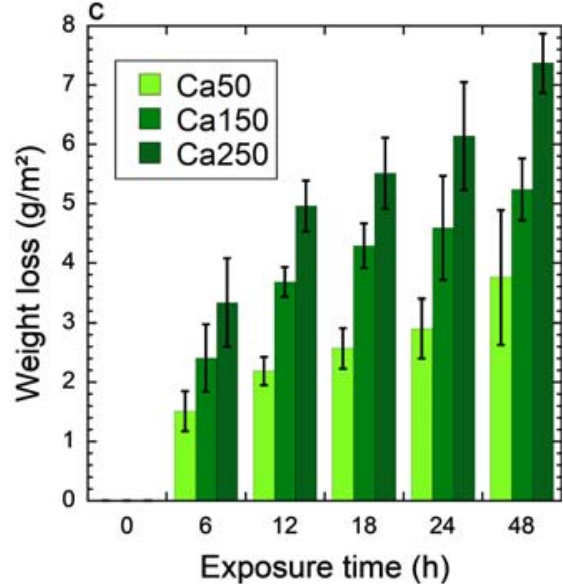

with $50-150 \mathrm{mg} / \mathrm{L}$ active chlorine of $\mathrm{NaClO}(\mathbf{b})$ or $\mathrm{Ca}(\mathrm{ClO})_{2}$ (c) during $24 \mathrm{~h}$, followed by fresh artificial tap water for $24 \mathrm{~h}$
Fig. 1 Accumulative weight loss $\left(\mathrm{g} / \mathrm{m}^{2}\right)$ of steel in selected solutions: artificial tap water (ATW), and ozone treatment during the first $30 \mathrm{~min}$ followed by fresh artificial tap water for up to $48 \mathrm{~h}$ (a); artificial tap water 
SEM images clearly reflect the weight loss measurements, that is, the lowest extent of corrosion in artificial tap water, followed by ozone treatment, and the hypochlorite solution treatments, which show a larger extent of corrosion with increasing active chlorine concentrations (Fig. 2). Despite rinsing with ultrapure water after treatment, the hypochlorite solutions seemed to influence the extent and composition of the corrosion deposit (Fig. 2). Sodium was detected in corrosion products of the $\mathrm{NaClO}$-treated samples to a greater extent as compared with the other treated samples, and calcium was detected to a greater extent on the samples previously treated with $\mathrm{Ca}(\mathrm{ClO})_{2}$. Chlorine was only detected for the samples previously treated with hypochlorite solutions. Note that all samples have been treated in artificial tap water, which contains small amounts of, among others, calcium, sodium, potassium, and chlorides. Cracks and local defects were visible in all surface disinfection treated samples.
The dissolved iron concentration after immersion of the steel samples in different solutions was determined by AAS analysis directly after treatment and the acidification by nitric acid to a $\mathrm{pH}$ less than 2 . In general, the iron concentration was relatively low, a few $\mathrm{mg} / \mathrm{L}$. There was a clear decreasing trend with time for artificial tap water and for the ozone treatment, whereas a similar but less clear trend was observed for hypochlorite treatment. This is as expected for thermodynamically unstable aqueous iron at $\mathrm{pH}$ values exceeding $\mathrm{pH} 7.5$ (Beverskog \& Puigdomenech 1996) (Fig. 3a). Artificial tap water and ozone-treated artificial tap water seemed to keep a greater extent of iron in solution as compared with the more alkaline hypochlorite solutions (Fig. 3a-c). Chemical speciation modeling results are presented in Table 2. The second (lower) $\mathrm{pH}$ value for the hypochlorite solution represents the final measured $\mathrm{pH}$ value after $24 \mathrm{~h}$. It is clear from Table 2 and Fig. 3 that the theoretical solubility of iron in artificial tap
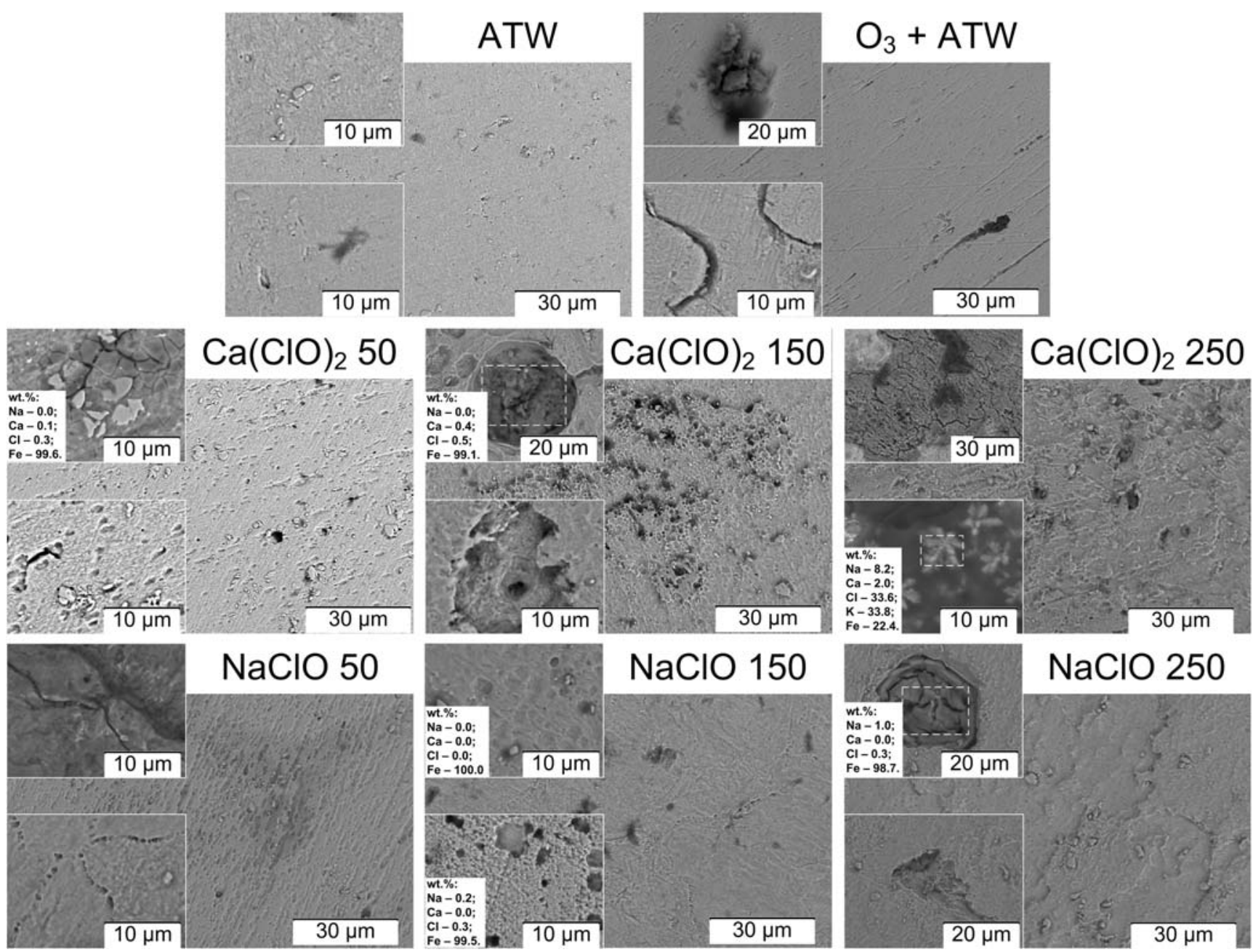

$\mathrm{NaClO} 250$

Fig. 2 Scanning electron microscopy images $(\times 2000$ magnification $)$ of the surface of steel after $24 \mathrm{~h}$ of treatment (rinsed with ultrapure water). Treatments: ATW (artificial tap water), $\mathrm{O}_{3}+$ ATW: 30 min ozone treatment followed by $23.5 \mathrm{~h}$ continued exposure in artificial tap water

without ozone, $\mathrm{Ca}(\mathrm{ClO})_{2}$ or $\mathrm{NaClO}$ treatments of 50,150 , or $250 \mathrm{mg} / \mathrm{L}$ active chlorine in artificial tap water for $24 \mathrm{~h}$. Mass concentrations measured by energy dispersive X-ray spectroscopy are indicated for selected samples 

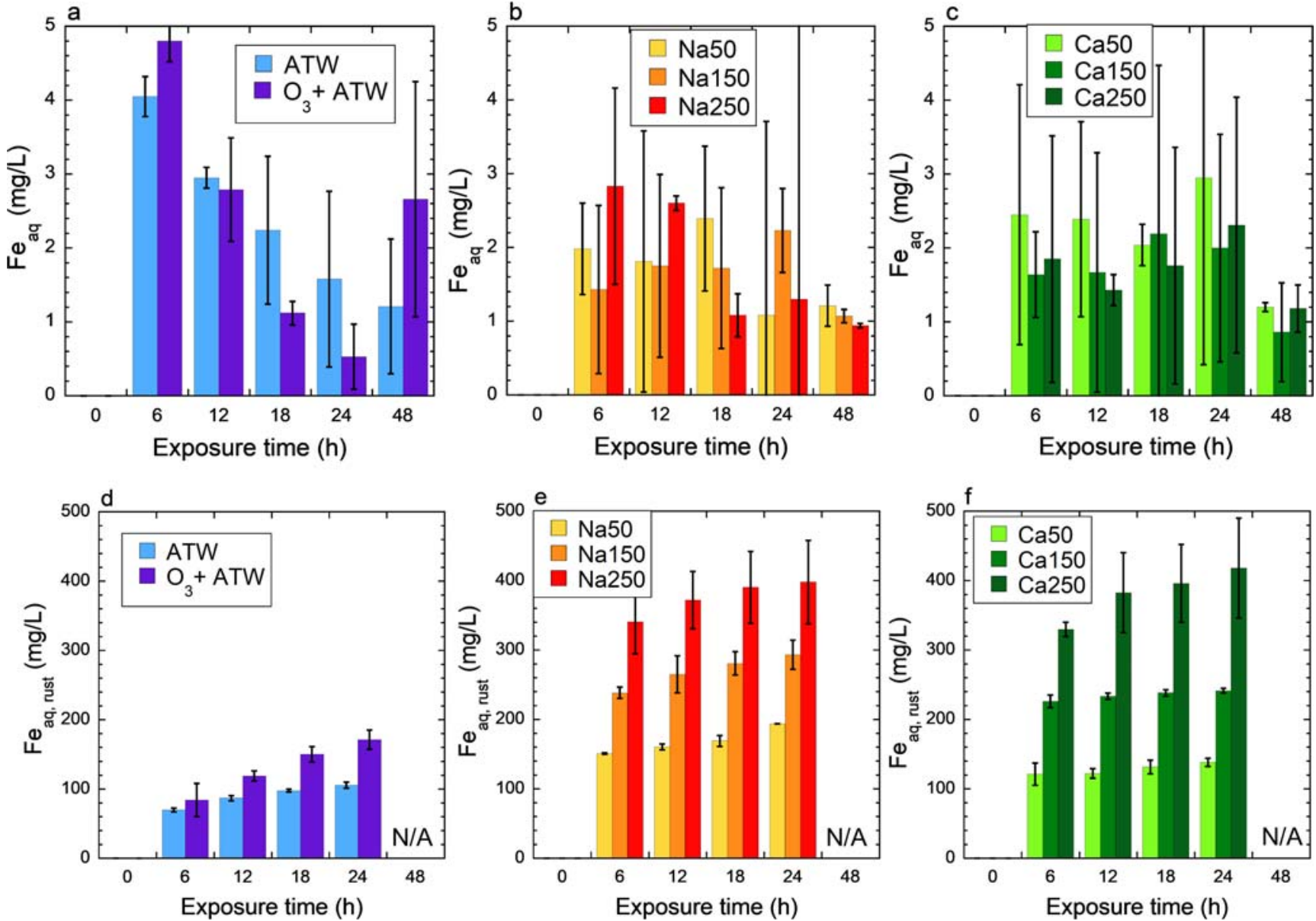

Fig. 3 Iron in solution $\left(\mathrm{Fe}_{\mathrm{aq}}\right)$ after treatments $(\mathbf{a}-\mathbf{c})$ and from corrosion products after treatments rinsed by citric acid and dissolved in nitric acid (d, e, $\mathrm{Fe}_{\mathrm{aq}}$, rust). Treatments: ATW (artificial tap water), $\mathrm{O}_{3}+\mathrm{ATW}$ : $30 \mathrm{~min}$ ozone treatment followed by $23.5 \mathrm{~h}$ continued exposure in

artificial tap water without ozone $(\mathbf{a}, \mathbf{d}), \mathrm{NaClO}(\mathbf{b}, \mathbf{e})$ or $\mathrm{Ca}(\mathrm{ClO})_{2}(\mathbf{c}, \mathbf{f})$ treatments of 50,150 , or $250 \mathrm{mg} / \mathrm{L}$ active chlorine in artificial tap water for $24 \mathrm{~h}$. These treatments were followed by fresh ATW for another $24 \mathrm{~h}$ (denoted 48 h) $(\mathbf{a}-\mathbf{c})$. N/A, not analyzed

water is even lower than that measured after $48 \mathrm{~h}$ of exposure in artificial tap water, which explains the decreasing concentrations measured over time. The measured concentrations of

iron in the hypochlorite solutions after $24 \mathrm{~h}$ are slightly higher (1-2 mg/L iron) than those predicted in solution (about $1 \mathrm{mg} /$ $\mathrm{L}$, Table 2). The opposite is the case for the sodium

Table 2 Predominating species as calculated by JESS (input values in Table 1 and "Chemical speciation modeling"). $\mathrm{pH}$ values represent the measured $\mathrm{pH}$ values (in the case of hypochlorite solutions showing first the initial and then the final $\mathrm{pH}$ ). a.ch., active chlorine; $s$, solid; $a q$, aqueous

\begin{tabular}{|c|c|}
\hline Solution & Predominating species \\
\hline Artificial tap water (ATW) & $\mathrm{pH}$ 7.5: $100 \mathrm{mg} / \mathrm{L}(100 \%) \alpha-\mathrm{Fe}_{2} \mathrm{O}_{3}(\mathrm{~s}), 36 \mu \mathrm{g} / \mathrm{L}(0 \%) \mathrm{FeOH}_{5}{ }^{2-}$ (aq) \\
\hline $\mathrm{ATW}+50 \mathrm{mg} / \mathrm{L}$ a.ch. $\mathrm{NaClO}$ & $\begin{array}{l}\text { pH 9: } 61 \mathrm{mg} / \mathrm{L}(61 \%) \alpha-\mathrm{Fe}_{2} \mathrm{O}_{3}(\mathrm{~s}), 39 \mathrm{mg} / \mathrm{L}(39 \%) \mathrm{FeOH}_{5}{ }^{2-} \text { (aq). } \\
\text { pH 8.3: } 99 \mathrm{mg} / \mathrm{L}(98 \%) \alpha-\mathrm{Fe}_{2} \mathrm{O}_{3}(\mathrm{~s}), 1.5 \mathrm{mg} / \mathrm{L}(2 \%) \mathrm{FeOH}_{5}{ }^{2-} \text { (aq). }\end{array}$ \\
\hline $\mathrm{ATW}+150 \mathrm{mg} / \mathrm{L}$ a.ch. $\mathrm{NaClO}$ & $\begin{array}{l}\text { pH 9.7: } 101 \mathrm{mg} / \mathrm{L}(100 \%) \mathrm{FeOH}_{5}{ }^{2-}(\mathrm{aq}) . \\
\text { pH 8.5: } 97 \mathrm{mg} / \mathrm{L}(96 \%) \alpha-\mathrm{Fe}_{2} \mathrm{O}_{3}(\mathrm{~s}), 4.0 \mathrm{mg} / \mathrm{L}(4 \%) \mathrm{FeOH}_{5}{ }^{2-} \text { (aq). }\end{array}$ \\
\hline $\mathrm{ATW}+250 \mathrm{mg} / \mathrm{L}$ a.ch. $\mathrm{NaClO}$ & $\begin{array}{l}\text { pH 10: } 101 \mathrm{mg} / \mathrm{L}(100 \%) \mathrm{FeOH}_{5}{ }^{2-}(\mathrm{aq}) \\
\text { pH 8.6: } 94 \mathrm{mg} / \mathrm{L}(93 \%) \alpha-\mathrm{Fe}_{2} \mathrm{O}_{3}(\mathrm{~s}), 6.5 \mathrm{mg} / \mathrm{L}(7 \%) \mathrm{FeOH}_{5}{ }^{2-} \text { (aq). }\end{array}$ \\
\hline $\mathrm{ATW}+50 \mathrm{mg} / \mathrm{L}$ a.ch. $\mathrm{Ca}(\mathrm{ClO})_{2}$ & $\begin{array}{l}\text { pH 8.5: } 97 \mathrm{mg} / \mathrm{L}(96 \%) \alpha-\mathrm{Fe}_{2} \mathrm{O}_{3}(\mathrm{~s}), 4.0 \mathrm{mg} / \mathrm{L}(4 \%) \mathrm{FeOH}_{5}{ }^{2-} \text { (aq). } \\
\text { pH 8.2: } 100 \mathrm{mg} / \mathrm{L}(99 \%) \alpha-\mathrm{Fe}_{2} \mathrm{O}_{3}(\mathrm{~s}), 1.0 \mathrm{mg} / \mathrm{L}(1 \%) \mathrm{FeOH}_{5}{ }^{2-} \text { (aq). }\end{array}$ \\
\hline $\mathrm{ATW}+150 \mathrm{mg} / \mathrm{L}$ a.ch. $\mathrm{Ca}(\mathrm{ClO})_{2}$ & $\begin{array}{l}\text { pH 8.6: } 94 \mathrm{mg} / \mathrm{L}(93 \%) \alpha-\mathrm{Fe}_{2} \mathrm{O}_{3}(\mathrm{~s}), 6.7 \mathrm{mg} / \mathrm{L}(7 \%) \mathrm{FeOH}_{5}{ }^{2-} \text { (aq). } \\
\mathrm{pH} \text { 8.2: } 99 \mathrm{mg} / \mathrm{L}(99 \%) \alpha-\mathrm{Fe}_{2} \mathrm{O}_{3}(\mathrm{~s}), 1.1 \mathrm{mg} / \mathrm{L}(1 \%) \mathrm{FeOH}_{5}{ }^{2-} \text { (aq). }\end{array}$ \\
\hline $\mathrm{ATW}+250 \mathrm{mg} / \mathrm{L}$ a.ch. $\mathrm{Ca}(\mathrm{ClO})_{2}$ & $\begin{array}{l}\text { pH 8.7: } 89 \mathrm{mg} / \mathrm{L}(89 \%) \alpha-\mathrm{Fe}_{2} \mathrm{O}_{3}(\mathrm{~s}), 11 \mathrm{mg} / \mathrm{L}(11 \%) \mathrm{FeOH}_{5}{ }^{2-} \text { (aq). } \\
\mathrm{pH} \text { 8.2: } 99 \mathrm{mg} / \mathrm{L}(99 \%) \alpha-\mathrm{Fe}_{2} \mathrm{O}_{3}(\mathrm{~s}), 1.1 \mathrm{mg} / \mathrm{L}(1 \%) \mathrm{FeOH}_{5}{ }^{2-} \text { (aq). }\end{array}$ \\
\hline
\end{tabular}


hypochlorite solution at high active chlorine (150-250 mg/L) and therefore high $\mathrm{pH}$ values, predicting about $4-6.5 \mathrm{mg} / \mathrm{L}$ iron as $\mathrm{FeOH}_{5}{ }^{2-}$ in solution, while $1-3 \mathrm{mg} / \mathrm{L}$ iron were analyzed. The large error bars may reflect on-going precipitation processes resulting in high variance among independent samples.

A citric acid rinsing procedure was used to remove solid corrosion products, followed by further acidifying in nitric acid. Most of the corrosion products were dissolved in citric and nitric acid, and the soluble iron in solution was only $1-5 \%$ of the iron in citric and nitric acid dissolved corrosion products (Fig. 3). The amount of dissolved iron from corrosion products follows the trends observed with weight loss measurements (Fig. 3). The corrosion products were however not completely soluble in citric acid and nitric acid, which was especially evident for longer exposure times (Fig. S6 (supplementary information)). For the shortest exposure time point, $6 \mathrm{~h}$, all corrosion products of artificial tap water-treated steel were soluble in citric and nitric acid, but for steel treated in $50 \mathrm{mg} / \mathrm{L}$ active chlorine $\mathrm{Ca}(\mathrm{ClO})_{2}$ for $24 \mathrm{~h}, 70 \%$ of the corrosion products were insoluble (Fig. S6), as determined from the difference in weight loss and measured iron in solution (corrosion products dissolved by citric and nitric acids and released iron).

EDS analysis of the insoluble corrosion products revealed the presence of calcium and iron for corrosion products obtained from both sodium and calcium hypochlorite treatments (Fig. S7 (supplementary material)). This demonstrates that a calcium- and iron-containing corrosion product is formed during prolonged treatment times, and that it is insoluble in citric and nitric acid.

The potentiodynamic curves for the steels in selected solutions of artificial tap water, artificial tap water during and after injection of ozone, and sodium and calcium hypochlorite solutions are shown in Fig. 4. The corresponding electrochemical parameters extracted from the polarization curves are summarized in Table 3.

Hypochlorite treatment resulted in the highest corrosion current densities, with the highest corrosion current densities at $150 \mathrm{mg} / \mathrm{L}$ active chlorine (Table 3 and Fig. 4). The corrosion current density in artificial tap water with $150 \mathrm{mg} / \mathrm{L}$ of active chlorine was 4.1 and 3.9 times higher for sodium and calcium hypochlorite solutions compared with artificial tap water. Two hundred fifty milligrams per liter active chlorine hypochlorite solutions showed instead a slightly lower corrosion current density as compared with $150 \mathrm{mg} / \mathrm{L}$ solutions, most probably related to a more rapid passivation or a higher $\mathrm{pH}$ value (see $\mathrm{pH}$ values reported Fig. 5). The corrosion current density during the ozone injection was a 2-fold higher compared with artificial tap water. Cessation of the ozone injection resulted in a reduction of the corrosion current density by $30 \%$. From the corrosion current density, the weight loss can be calculated by Faraday's law, as shown in the supplementary material. Figures S8 and S9 (supplementary material) show that this calculated weight loss was equal or larger as compared with the weight loss measured directly after $6 \mathrm{~h}$ of exposure (Fig. 1). The larger weight loss estimated from the electrochemical measurements is probably an effect of linear extrapolation from the electrochemical measurements that were conducted during 15 min as compared with the weight loss after $6 \mathrm{~h}$.

Open-circuit potential over time was also measured for $24 \mathrm{~h}$ for the different surface disinfectant treatment conditions (Fig. S10 (supplementary material)). For all solutions, the open-circuit potential first decreased with time and then stabilized at a low value, showing an active corrosion behavior. The stabilization time was found to depend on the solution composition and $\mathrm{pH}$. For artificial tap water solutions of different $\mathrm{pH}$ values, an increased $\mathrm{pH}$ resulted in a longer stabilization time and a higher stabilization open-circuit potential. The $\mathrm{pH}$ seemed to be the main factor influencing the stabilization time and stabilization potential in all solutions (Fig. S10), with the exception of the high active chlorinecontaining solutions (Fig. S10c, e) that have a shorter stabilization time than what would be expected from their $\mathrm{pH}$ value alone (Fig. S10a). After the treatment for $24 \mathrm{~h}$ in chlorinecontaining disinfectants, the loosely attached corrosion products were rinsed off from the samples with ultrapure water and their OCP was measured for the next $24 \mathrm{~h}$ in artificial tap water. The leaching of hypochlorite from pores increased the $\mathrm{pH}$ of the artificial tap water for the samples that previously had been treated by hypochlorite (Figs. S10d and S10f).

After the $24 \mathrm{~h}$ treatments, the corrosion products were mechanically removed and dried in ambient air. They were then analyzed by means of SEM, EDS, and Raman spectroscopy (Fig. 5 and Table S5 (supplementary material)). The morphology of corrosion products after the sodium (Figs. 5a, b) and calcium (Fig. 5c, d) hypochlorite treatments was slightly different. Both needle-shaped, platelets, and spherical particles were found, without any obvious difference in composition measured by EDS mapping, with one exception (the large particle to the top left in Fig. 5d is calcium-rich and irondepleted). There was however a clear difference in composition for the sodium compared with calcium hypochloritetreated steel corrosion products: sodium was only present in sodium hypochlorite-treated corrosion products, and calcium was (to a lower extent) only present in calcium hypochloritetreated corrosion products (Table S5). The atomic ratio between iron and oxygen (oxygen contains contributions from other oxides and organic atmospheric contaminants) was 0.36 \pm 0.20 for sodium and $0.38 \pm 0.11$ for calcium hypochloritetreated steel corrosion products. Clear Raman peaks were found at $210-220 \mathrm{~cm}^{-1}$ in all cases (Fig. 5e). A broader peak at $250-290 \mathrm{~cm}^{-1}$ was found for artificial tap water- and $\mathrm{Ca}(\mathrm{ClO})_{2}$-treated steels. Ozone-treated steel revealed a narrower peak at $250 \mathrm{~cm}^{-1}$ and $\mathrm{NaClO}$-treated steel at 
Fig. 4 Potentiodynamic polarization curves (scan rate $0.5 \mathrm{mV} / \mathrm{s}$ scanning in anodic direction) in artificial tap water (ATW, a), during ozone treatment and after ozone treatment of $30 \mathrm{~min}$ (b), and in different hypochlorite solutions with active chlorine concentrations of 50$250 \mathrm{mg} / \mathrm{L}$ (c, d). Representative curves of two measurements are shown. All measurements were conducted after 5 min of open circuit potential
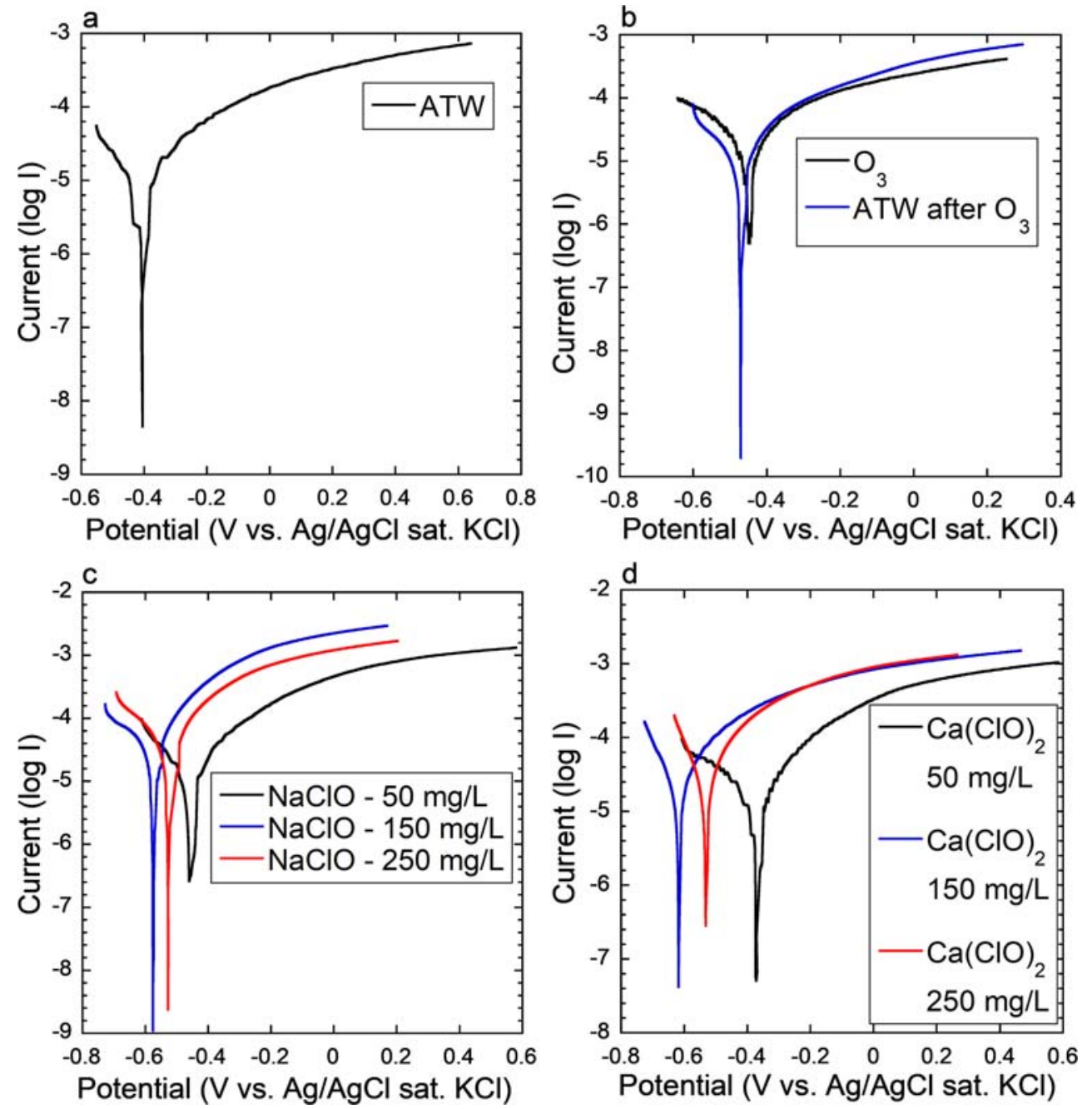

$285 \mathrm{~cm}^{-1}$. These peaks, as well as the peak at $1300 \mathrm{~cm}^{-1}$ present for all samples, indicate hematite $\left(\alpha-\mathrm{Fe}_{2} \mathrm{O}_{3}\right)(\mathrm{De}$ Faria et al. 1997). For the ozone-treated sample, small amounts of lepidocrocite $(\gamma-\mathrm{FeO}(\mathrm{OH}))$ could also be present, showing peaks at 250, 370, 500 (shoulder), 520, 650 (shoulder), 720, and $1300 \mathrm{~cm}^{-1}$ (De Faria et al. 1997). For both hypochlorite solutions, an additional clear peak at around $380-390 \mathrm{~cm}^{-1}$ is present. This is most probably related to the $\mathrm{Fe}-\mathrm{Cl}$ band (Réguer et al. 2007), either from $\mathrm{FeCl}_{3}$, which is characterized by two peaks at 400 and $600 \mathrm{~cm}^{-1}$ (Zhou et al. $2017)$, or from akaganéite $(\beta-\mathrm{FeO}(\mathrm{OH}, \mathrm{Cl}))$, which has main peaks at 307 and $387 \mathrm{~cm}^{-1}$ (Réguer et al. 2007), or a combination of these. Both EDS and Raman spectroscopy analyses suggest the presence of chlorine- and iron-containing corrosion products in the case of treatment with hypochlorite solutions.

Environmental impact assessment at life cycle stages (life cycle impact assessment-LCIA) was conducted on the different surface disinfection technologies of water supply facilities using sodium and calcium hypochlorite $(150 \mathrm{mg} / \mathrm{L}$ active chlorine) and ozonated water (1 mg/L). As follows from the results of the inventory analysis (Figs. S3-S5, Tables S2-S4), the considered options for the different surface disinfection treatments of water supply facilities were characterized by environmental aspects such as the consumption of raw materials and energy, emissions of pollutants into the atmospheric air, wastewater discharges into water bodies or local sewer network, and waste generation. The lowest value of the ecoindicator (Dreyer et al. 2003, Goedkoop 1999) corresponded to the use of ozone (Fig. 6). Calcium hypochlorite had the highest impact on the environment among all but three impact categories (Fig. 6). Sodium hypochlorite had the highest impact in the freshwater ecotoxicity category. Ozone had the most detrimental environmental effect in the categories ozone depletion and ionizing radiation.

\section{Discussion}

Worldwide, most surface disinfection treatments for water facilities rely on chlorine-containing disinfectants. A systematic choice of the best possible surface disinfectant should, beside 
Table 3 Electrochemical parameters extracted from potentiodynamic polarization measurements. Average and standard deviations of two independent measurements are shown

\begin{tabular}{lllll}
\hline Solution & $\mathrm{E}_{\text {corr, }}, \mathrm{mV}$ & $\mathrm{i}_{\text {corr, }} \mu \mathrm{A} / \mathrm{cm}^{2}$ & Cathodic $\beta, \mathrm{mV}$ & Anodic $\beta, \mathrm{mV}$ \\
\hline Artificial tap water & $-401.6 \pm 4.1$ & $6.7 \pm 0.6$ & $144.4 \pm 4.0$ & $87.3 \pm 5.2$ \\
$\mathrm{NaClO} 50 \mathrm{mg}$ a.ch./L & $-456.1 \pm 5.1$ & $19.1 \pm 1.1$ & $210.3 \pm 40.8$ & $173.9 \pm 60.5$ \\
$\mathrm{NaClO} 150 \mathrm{mg}$ a.ch./L & $-591.5 \pm 15.2$ & $20.3 \pm 5.6$ & $108.5 \pm 19.5$ & $104.4 \pm 13.4$ \\
$\mathrm{NaClO} 250 \mathrm{mg}$ a.ch./L & $-524.6 \pm 7.4$ & $25.5 \pm 3.5$ & $104.6 \pm 7.6$ & $101.4 \pm 15.0$ \\
$\mathrm{Ca}(\mathrm{ClO})_{2} 50 \mathrm{mg}$ a.ch./ & $-387.2 \pm 22.4$ & $17.5 \pm 3.2$ & $204.6 \pm 20.3$ & $146.4 \pm 21.5$ \\
$\mathrm{Ca}(\mathrm{ClO})_{2} 150 \mathrm{mg}$ a.ch./L & $-589.4 \pm 43.4$ & $19.5 \pm 1.5$ & $120.1 \pm 25.0$ & $122.1 \pm 16.6$ \\
$\mathrm{Ca}(\mathrm{ClO})_{2} 250 \mathrm{mg}$ a.ch./L & $-548.6 \pm 20.6$ & $21.1 \pm 1.1$ & $102.0 \pm 31.6$ & $100.6 \pm 18.4$ \\
$\mathrm{O}_{3}$ during 30 min treatment & $-445.9 \pm 0.04$ & $10.0 \pm 1.1$ & $102.1 \pm 5.6$ & $92.6 \pm 8.5$ \\
after 30 min treatment of $\mathrm{O}_{3}$ & $-469.0 \pm 2.2$ & $7.1 \pm 1.8$ & $115.0 \pm 7.0$ & $96.4 \pm 7.7$ \\
\hline
\end{tabular}

$E_{\text {corr }}$, corrosion potential; $i_{c o r r}$, corrosion current density; a.ch., active chlorine; hypochlorite- and ozone-treated solutions in artificial tap water their disinfection efficiency, include considerations such as environmental impact, risk for corrosion of water facilities (and thereby water quality and life time), and costs. The test conditions of this study were chosen based on common and recommended test conditions for surface disinfection treatments of water facilities with hypochlorite and ozone. Previous studies have shown that the efficiency of ozone treatment for $30 \mathrm{~min}$ is comparable or better than that of hypochlorite solution treatments for $24 \mathrm{~h}$ (Романовский et al. 2016).

\section{Comparison of surface disinfectants for water facilities-corrosion perspective}

This study shows that, from a corrosion perspective, treatment with ozone is preferable over hypochlorite treatments. We base this statement on the following observations: (i) there is a lower corrosion rate during ozone treatment as compared with hypochlorite solutions, and (ii) there is no risk of trapping chlorinecontaining corrosion products or hypochlorite species in pores and surface defects after the surface disinfection treatments.

The results of this study are limited by its boundary conditions, e.g., it is only valid at room temperature and for the active chlorine concentrations used. The $\mathrm{pH}$ was influenced by the hypochlorite concentration and not buffered, similar to what would be expected in water facilities. It is not totally clear from our results whether the $\mathrm{pH}$ or the hypochlorite concentration influences the corrosion rate to a greater extent, and most probably the effects seen are influenced by both parameters. The $\mathrm{pH}$ was found to affect the kinetics of open-circuit potential relaxation towards the steady state value, the steady state opencircuit potential value, and the amount of iron that was dissolved in solution. Despite the generally passivating effect of alkaline $\mathrm{pH}$ values for steel (Schmuki et al. 1999), the effect of increasing hypochlorite concentration, and thus higher solution $\mathrm{pH}$, was found to result in increased corrosion as evident by weight loss measurements and corrosion product analysis.

There are at present relatively few studies related to corrosion of steel in hypochlorite solutions and dissolved ozone in media of relevance for ground water. Our study agrees with the conclusions of one study on mild steel in hypochlorite solution, showing that corrosion rates increase with freely available chlorine concentrations (Gaur et al. 1994). Our study, even though not directly comparable, is consistent with the conclusions of another study (Wu et al. 2014) on carbon steel that corroded more in the presence of ozone in air.

The relatively strongly decreased $\mathrm{pH}$ observed during hypochlorite exposure of steel could be explained by the consumption of $\mathrm{OH}^{-}$ions according to the following reaction (Talaiekhozani et al. 2017):

$2 \mathrm{Fe}(\mathrm{OH})_{3}+3 \mathrm{ClO}^{-}+4 \mathrm{OH}^{-} \rightarrow 2 \mathrm{FeO}_{4} 2^{-}+3 \mathrm{Cl}^{-}+5 \mathrm{H}_{2} \mathrm{O}$

This is supported by the observation that no corresponding $\mathrm{pH}$ decrease was observed during $\mathrm{pH}$ reference measurements of hypochlorite solutions in the absence of steel (data not shown).

Further mechanistic insights in the corrosion of steel in hypochlorite containing and ozonated artificial tap water solutions are not possible from this study alone. However, it has been suggested in the literature that oxidation of mild steel in ozonated sea water results in the formation of a protective surface oxide due to the incorporation of calcium and magnesium ions in the surface film (Liao et al. 2012). This is supported by our observation that $\mathrm{Ca}$-containing insoluble corrosion products formed increasingly with exposure time. This also suggests that the addition of inhibitors during ozone treatment could further reduce the corrosion rate of steel in water facilities, which should be investigated in future studies.

\section{Comparison of surface disinfectants for water facilities-environmental perspective}

From an environmental perspective, the ozone treatment has an advantage over the hypochlorite treatments, as no/limited waste products are generated. Although ozone is classified in 
Fig. 5 Scanning electron microscopy images of corrosion products for the corrosion products obtained after $24 \mathrm{~h}$ of treatment in sodium $(\mathbf{a}, \mathbf{b})$ and calcium $(\mathbf{c}, \mathbf{d})$ hypochlorite in artificial tap water $(150 \mathrm{mg} / \mathrm{L}$ active chlorine). e Average (of two independent samples acquired for $180 \mathrm{~s}$ each) Raman spectra for the corrosion products obtained after $24 \mathrm{~h}$ of treatment in artificial tap water, ozone in artificial tap water (30 min followed by $23.5 \mathrm{~h}$ without ozone), and hypochlorite in artificial tap water $(150 \mathrm{mg} / \mathrm{L}$ active chlorine). The spectra are off-set for clarity. Single spectra are shown in Fig. S11 (supplementary material)
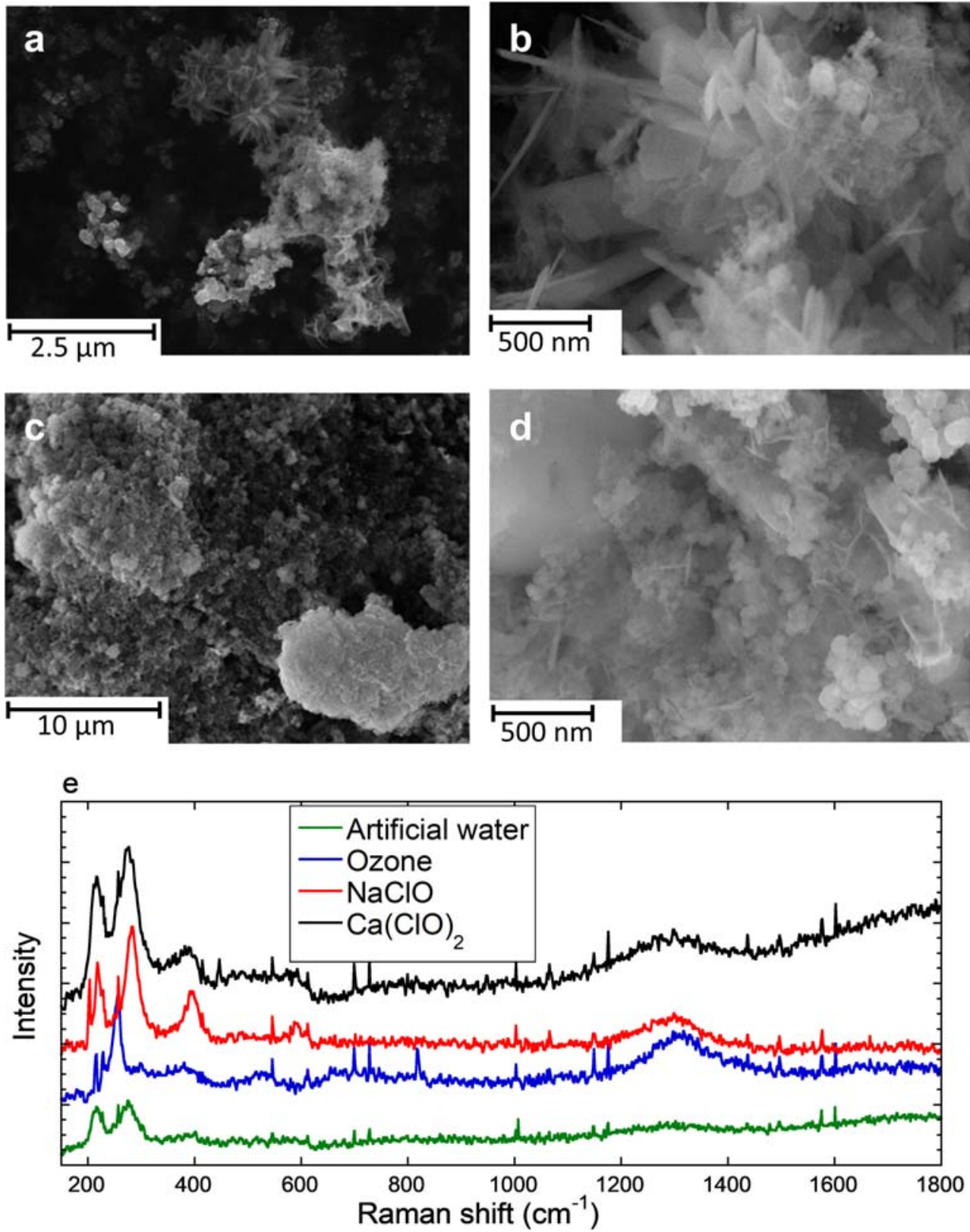

similar hazard classes as sodium hypochlorite regarding aquatic life (ECHA 2019a), it has the advantage that it can directly be generated in the water facility in a closed system and that its half lifetime is on average $20 \mathrm{~min}$. This results in significantly lower impact on the environment of ozone treatment as compared with sodium or calcium hypochlorite treatments.

The highest environmental impact of calcium hypochlorite on the environment among the surface disinfectants can mainly be explained by the significant environmental impact during its production phase. It should also be noted that the preparation of a fresh surface disinfectant solution of calcium hypochlorite includes an initial preparation at $10 \mathrm{wt} \%$, which then should be stored for $24 \mathrm{~h}$, filtered from insoluble sediments, and finally be diluted to the needed concentration. In contrast, the production of sodium hypochlorite includes only electrolysis of sodium chloride on site. For the final surface disinfectant solution of sodium hypochlorite, this byproduct solution is only diluted, without any formation of sediments. Ozone is generated and injected into the water immediately during the treatment.

Life cycle impact assessments of surface disinfection treatments of water facilities are scarce, while they are relatively common for water or wastewater disinfection treatments (Dong et al. 2017, Mo et al. 2018). In these studies, it was found that ozone has a lower environmental impact as compared with chlorine-containing disinfectants, which agrees with this study on surface disinfection. 


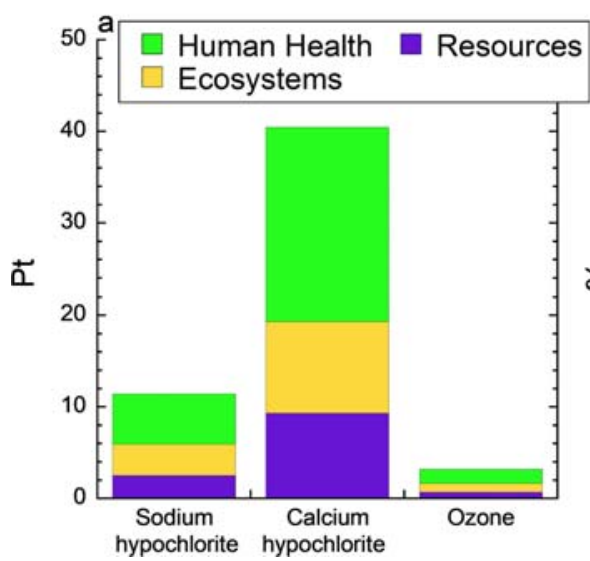

Fig. 6 Environmental impact assessment of sodium hypochlorite, calcium hypochlorite, and ozone: single score (a) and characterization (b), where: 1-climate change human health; 2-ozone depletion; 3 human toxicity; 4 - photochemical oxidant formation; 5-particulate matter formation; 6 -ionizing radiation; 7 - climate change ecosystems;

\section{Comparison of surface disinfectants for water facilities-other aspects}

Except life cycle impact assessment and lifetime of the material related to corrosion, important aspects to consider for surface disinfection of water facilities are the time, which in practice means a stop of the drinking water produced, and the easiness of operation. If it takes long time and requires handling of chemicals, flushing, and waste effluents, the surface disinfection treatment will be delayed more commonly and is less preferred. For these aspects, ozone requiring the shortest time of treatment $(30 \mathrm{~min})$ as compared with 1 day for chlorine-based treatments shows a clear advantage. It furthermore requires the least chemical and waste handling.

\section{Conclusions}

This study compared steel corrosion and life cycle impact assessment of different surface disinfection treatments for internal surfaces of water facilities, such as boreholes, filters, pipes, and reservoirs, using hypochlorite-based and ozonebased processes. The following main conclusions were drawn:

1. The steel corroded actively in all solutions of $\mathrm{pH} 7.5$ or higher; however, most severe corrosion occurred in the hypochlorite solutions of highest concentration.

2. The ozone treatment caused significantly less corrosion as compared with the sodium or calcium hypochlorite treatments with $150-250 \mathrm{mg} / \mathrm{L}$ active chlorine.

3. Hypochlorite or chlorine-containing compounds were trapped in corrosion products, defects, and cracks after the surface disinfection treatment with hypochlorite and were shown to influence the $\mathrm{pH}$ and open-circuit potential in subsequent exposure to artificial tap water. Trapped chlorine-containing compounds are likely to influence the corrosion of steel after surface disinfection treatments.

4. The amount of released and soluble iron to the tap water solutions was significantly lower (about $1 \%$ ) as compared with the total oxidized mass of iron under given experimental conditions. This agreed with chemical speciation modeling.

5. Life cycle impact assessment revealed ozone to have the lowest negative impact on the environment, while calcium hypochlorite had the highest environmental impact due to its production phase.

6. In all, corrosion, life cycle impact assessment, and handling differences (preparation, handling, and waste) all prefer ozone for a surface disinfection treatment of water facilities.

Acknowledgments Open access funding provided by Royal Institute of Technology. Valentin Romanovski is grateful for a scholarship from the Swedish Institute within the Visby program and for the financial support of the Ministry of Science and Higher Education of the Russian Federation in the framework of Increase Competitiveness Program of NUST «MISiS» (№ K2-2019-007), implemented by a governmental decree dated 16th of March 2013, N 211. The authors thank Jonas Hedberg for some useful references and for help with operating the Raman Spectrometer. The authors thank Peter May for valuable discussions and help regarding the JESS software for chemical speciation modeling.

Author contributions V.R. conducted all experiments and most calculations including the environmental impact assessment and drafted the manuscript. P.M.C. read the manuscript and gave valuable comments to data presentation and explanation. Y.H. supervised the electrochemical measurements, corrosion experiments, use of plotting and statistical software, and assisted in paper drafting and submission. All authors read and approved the final version of the manuscript.

Funding information Visby Scholarship Offer 021492017 from Swedish Institute. Ministry of Science and Higher Education of the Russian Federation in the framework of Increase Competitiveness 
Program of NUST «MISiS» (№ K2-2019-007), implemented by a governmental decree dated 16th of March 2013, N 211.

\section{Compliance with ethical standards}

Conflict of interest The authors declare that they have no conflict of interest.

Open Access This article is licensed under a Creative Commons Attribution 4.0 International License, which permits use, sharing, adaptation, distribution and reproduction in any medium or format, as long as you give appropriate credit to the original author(s) and the source, provide a link to the Creative Commons licence, and indicate if changes were made. The images or other third party material in this article are included in the article's Creative Commons licence, unless indicated otherwise in a credit line to the material. If material is not included in the article's Creative Commons licence and your intended use is not permitted by statutory regulation or exceeds the permitted use, you will need to obtain permission directly from the copyright holder. To view a copy of this licence, visit http://creativecommons.org/licenses/by/4.0/.

\section{References}

American Water Works Association 2013 AWWA C653-13 Disinfection of water treatment plants. 9781613002513, https://doi.org/10. 12999/AWWA.C653.13

Bayo J, Angosto JM, Gómez-López MD (2009) Ecotoxicological screening of reclaimed disinfected wastewater by Vibrio fischeri bioassay after a chlorination-dechlorination process. J Hazard Mater 172: 166-171. https://doi.org/10.1016/j.jhazmat.2009.06.157

Beverskog B, Puigdomenech I (1996) Revised Pourbaix diagrams for iron at 25-300 C. Corros Sci 38:2121-2135

Bhuvaneshwari M, Eltzov E, Veltman B, Shapiro O, Sadhasivam G, Borisover M (2019) Toxicity of chlorinated and ozonated wastewater effluents probed by genetically modified bioluminescent bacteria and cyanobacteria Spirulina sp. Water Res 164:114910. https://doi. org/10.1016/j.watres.2019.114910

Brandt MJ, Johnson KM, Elphinston AJ, Ratnayaka DD (2016) Twort's water supply. Butterworth-Heinemann, Amsterdam

Bull RJ (1982) Health effects of drinking water disinfectants and disinfectant by-products. Env Sci Technol 16:554A-559A

De Faria D, Venâncio Silva S, De Oliveira M (1997) Raman microspectroscopy of some iron oxides and oxyhydroxides. J Raman Spectrosc 28:873-878

Dong S, Li J, Kim M-H, Park S-J, Eden JG, Guest JS, Nguyen TH (2017) Human health trade-offs in the disinfection of wastewater for landscape irrigation: microplasma ozonation vs. chlorination. Environ Sci: Water Res Technol 3:106-118

Dong S, Massalha N, Plewa MJ, Nguyen TH (2018) The impact of disinfection $\mathrm{Ct}$ values on cytotoxicity of agricultural wastewaters: ozonation vs. chlorination. Water Res 144:482-490. https://doi.org/ 10.1016/j.watres.2018.07.065

Dreyer LC, Niemann AL, Hauschild MZ (2003) Comparison of three different LCIA methods: EDIP97, CML2001 and eco-indicator 99. Int J Life Cycle Ass 8:191-200

ECHA 2016 Biocidal Products Committee opinions on active substance approval: active chlorine released from sodium hypochlorite, https:// echa.europa.eu/regulations/biocidal-products-regulation/approvalof-active-substances/bpc-opinions-on-active-substance-approval

ECHA (2019a) Ozone. https://echa.europa.eu/substance-information/-/ substanceinfo/100.030.051
ECHA (2019b) Sodium hypochlorite. https://echa.europa.eu/registrationdossier/-/registered-dossier/15516

ECHA (2019c) Calcium hypochlorite. https://echa.europa.eu/substanceinformation/-/substanceinfo/100.029.007

Gaur B, Singh A, Rao N (1994) Corrosion of mild steel in hypochlorite solution-an electrochemical and weight-loss study. Indian J Chem Technol 1:225-229

Gavin H (2019) The Levenberg-Marquardt algorithm for nonlinear least squares curve-fitting problems. Department of Civil and Environmental Engineering, Duke University http://people.duke. edu/ hpgavin/ce281/lm.pdf, 1-19

Geering F (1999) Ozone applications the state-of-the-art in Switzerland. Ozone-Sci Eng 21:187-200

Goedkoop M, Heijungs R, Huijbregts M, De Schryver A, Struijs J, van Zelm R (2009) ReCiPe:2008 https://www.leidenuniv.nl/cml/ssp/ publications/recipe characterisation.pdf

Goedkoop MJ (1999) The eco-indicator 99: a damage oriented method for life cycle impact assessment methodology report. Pre Concultants, https://www.pre-sustainability.com/download/EI99 annexe_v3.pdf

Greene AK, Few BK, Serafini JC (1993) A comparison of ozonation and chlorination for the disinfection of stainless steel surfaces. J Dairy Sci 76:3617-3620. https://doi.org/10.3168/jds.S0022-0302(93) 77702-4

Guzel-Seydim ZB, Greene AK, Seydim AC (2004) Use of ozone in the food industry. LWT-Food Sci Technol 37:453-460. https://doi.org/ 10.1016/j.lwt.2003.10.014

IHS Markit (2015) Hypochlorite bleaches, https://ihsmarkit.com/ products/hypochlorite-chemical-economics-handbook.html

ISO 6341:2012 (2012) Water quality - determination of the inhibition of the mobility of Daphnia magna Straus (Cladocera, Crustacea) Acute toxicity test

Jackson PJ, Dillon GR, Irving TE, Stanfield G 2001 Manual on treatment for small water supply systems, Drinking water inspectorate, http:// dwi.defra.gov.uk/research/completed-research/reports/DWI70_2_ 137 manual old.pdf

Jeong $\mathrm{CH}$, Wagner ED, Siebert VR, Anduri S, Richardson SD, Daiber EJ, McKague AB, Kogevinas M, Villanueva CM, Goslan EH (2012) Occurrence and toxicity of disinfection byproducts in European drinking waters in relation with the HIWATE epidemiology study. Env Sci Technol 46:12120-12128

Liao J, Kishimoto K, Yao M, Mori Y, Ikai M (2012) Effect of ozone on corrosion behavior of mild steel in seawater. Corros Sci 55:205-212. https://doi.org/10.1016/j.corsci.2011.10.020

May PM (2015) JESS at thirty: strengths, weaknesses and future needs in the modelling of chemical speciation. Appl Geochem 55:3-16

Mo W, Cornejo PK, Malley JP, Kane TE, Collins MR (2018) Life cycle environmental and economic implications of small drinking water system upgrades to reduce disinfection byproducts. Water Res 143: 155-164. https://doi.org/10.1016/j.watres.2018.06.047

Pascual A, Llorca I, Canut A (2007) Use of ozone in food industries for reducing the environmental impact of cleaning and disinfection activities. Trends Food Sci Tech 18:S29-S35

Rakness KL (2011) Ozone in drinking water treatment: process design, operation, and optimization. American Water Works Association

Réguer S, Neff D, Bellot-Gurlet L, Dillmann P (2007) Deterioration of iron archaeological artefacts: micro-Raman investigation on Clcontaining corrosion products. J Raman Spectrosc 38:389-397. https://doi.org/10.1002/jrs.1659

Salvato JA (1992) Enviornmental engineering and sanitation. Wiley, New York

Schmuki P, Büchler M, Virtanen S, Isaacs HS, Ryan MP, Böhni H (1999) Passivity of iron in alkaline solutions studied by in situ XANES and LASER reflexion technique. J Electrochem Soc 146:2097

Schulz C, Lohman S (2005) Method and apparatus for ozone disinfection of water supply pipelines. US patent app. 11/065,768 
Sleeswijk AW, van Oers LF, Guinée JB, Struijs J, Huijbregts MA (2008) Normalisation in product life cycle assessment: an LCA of the global and European economic systems in the year 2000. Sci Total Env 390:227-240

Sun H, Liu H, Han J, Zhang X, Cheng F, Liu Y (2018) Chemical cleaning-associated generation of dissolved organic matter and halogenated byproducts in ceramic MBR: ozone versus hypochlorite. Water Res 140:243-250. https://doi.org/10.1016/j.watres.2018.04. 050

Talaiekhozani A, Talaei MR, Rezania S (2017) An overview on production and application of ferrate (VI) for chemical oxidation, coagulation and disinfection of water and wastewater. J Environ Chem Eng 5:1828-1842. https://doi.org/10.1016/j.jece.2017.03.025

Varga K, Baradlai P, Hirschberg G, Németh Z, Oravetz D, Schunk J, Tilky P (2001) Corrosion behaviour of stainless steel surfaces formed upon chemical decontamination. Electrochim Acta 46:3783-3790. https://doi.org/10.1016/S0013-4686(01)00665-X

Villanueva CM, Fernandez F, Malats N, Grimalt JO, Kogevinas M (2003) Meta-analysis of studies on individual consumption of chlorinated drinking water and bladder cancer. J Epidemiol Commun Health 57: 166-173

World Health Organization (2011) Guidelines for drinking-water quality, 4th edition. WHO Chron 38:104-108

Wu Q, Van Y, Zhou H, Wu LM, Guo YP, Cai LK (2014) Initial stage corrosion behavior and mechanism of carbon steel exposed to ozone. Corr Protect 35:767-770

Zhou S, You K, Gao H, Deng R, Zhao F, Liu P, Ai Q, Luo H (2017) Mesoporous silica-immobilized $\mathrm{FeCl} 3$ as a highly efficient and recyclable catalyst for the nitration of benzene with $\mathrm{NO} 2$ to nitrobenzene. Mol Catal 433:91-99

Романовский ВИ, Гуринович АД, Бессонова ЮН, Крышилович ЕВ (2016) Технические аспекты использования озона в водоподготовке [Technical aspects of the ozone use for water treatment]. Вода Mag 2:36-41

Publisher's note Springer Nature remains neutral with regard to jurisdictional claims in published maps and institutional affiliations. 